\title{
Improved Homologous Expression of the Acidic Lipase from Aspergillus niger $^{\mathbb{S}}$
}

\author{
Si-Yuan Zhu, Yan Xu, and Xiao-Wei Yu* \\ Key Laboratory of Industrial Biotechnology, Ministry of Education, School of Biotechnology, Jiangnan University, Wuxi 214122, P.R. China
}

\author{
Received: June 14, 2019 \\ Revised: November 16, 2019 \\ Accepted: November 19, 2019 \\ First published online: \\ November 22, 2019 \\ ${ }^{*}$ Corresponding author \\ Phone: +86-510-85918201 \\ Fax: +86-510-85918201 \\ E-mail: yuxw@jiangnan.edu.cn \\ S upplementary data for this \\ paper are available on-line only at \\ http://jmb.or.kr. \\ pISSN 1017-7825, eISSN 1738-8872 \\ Copyright(C) 2020 by \\ The Korean Society for Microbiology \\ and Biotechnology
}

\begin{abstract}
In this study, the acidic lipase from Aspergillus niger (ANL) was homologously expressed in $A$. niger. The expression of ANL was significantly improved by the expression of the native ANL with the introns, the addition of the Kozak sequence and the optimization of the signal sequences. When the cDNA sequence of $A N L$ fused with the glaA signal was expressed under the gpdA promoter in $A$. niger, no lipase activity could be detected. We then tried to improve the expression by using the full-length ANL gene containing three introns, and the lipase activity in the supernatant reached $75.80 \mathrm{U} / \mathrm{ml}$, probably as a result of a more stable mRNA structure. The expression was further improved to $100.60 \mathrm{U} / \mathrm{ml}$ by introducing a Kozak sequence around the start codon due to a higher translation efficiency. Finally, the effects of three signal sequences including the cbhI signal, the ANL signal and the glaA signal on the lipase expression were evaluated. The transformant with the cbhI signal showed the highest lipase activity $(314.67 \mathrm{U} / \mathrm{ml})$, which was 1.90-fold and 3.13-fold higher than those with the ANL signal and the glaA signal, respectively. The acidic lipase was characterized and its highest activity was detected at $\mathrm{pH} 3.0$ and a temperature of $45^{\circ} \mathrm{C}$. These results provided promising strategies for the production of the acidic lipase from A. niger.
\end{abstract}

Keywords: Aspergillus niger, acidic lipase, expression, characterization, Agrobacterium-mediated transformation

\section{Introduction}

Aspergillus niger is one of the most important microorganisms in the production of organic acids and a wide range of enzymes [1]. Many substances produced in A. niger are considered as Generally Recognized as Safe (GRAS) by the United States Food and Drug Administration [1]. A variety of industrially important enzymes such as oxidases, cellulases, dehydrogenases, hydrolases and pectinases have been produced in $A$. niger [2]. In addition, other structurally complex antibody proteins or small peptides, such as nucleoside hydrolase, sterol 24-c-methyltransferase, humanized immunoglobulin G1 antibodies, cyclodepsipeptides (octa-enniatin and octa-beauvericin), were also successfully expressed in A. niger [3-6]. In recent years, $A$. niger has been used for the production of high-value recombinant antibodies with a lower cost since the protein produced in $A$. niger is processed more similarly to mammals [6, 7]. The products from A. niger have been widely applied in food, feed, bioenergy and pharmaceutical processes, amongst others [2].

Many attempts have been made to increase the expression of proteins in filamentous fungi [8], for example, by optimization of promoters and copy numbers, or expression as fusion protein [9-11]. The expression of xylanase was improved by 2.27 -fold through modification of the $g p d A$ promoter [12]. The A. niger glucoamylase gene is commonly used as a fusion tag for improvement of foreign gene expression in $A$. niger, including the porcine pancreatic prophospholipase A2 (proPLA2) gene [11], the human lymphotoxin alpha $(L T \alpha)$ gene [9] and the catalytic subunit of the bovine enterokinase (EKL) gene [10].

In addition, a superior host strain is very important to in achieving target protein expression at a high level. A host with a lower protein background could be obtained by disrupting the gene of the original high-yield protein in the 
strain. Without the interference of endogenous proteins, a higher yield could be obtained for recombinant proteins in the host. At present, tannase, xylanase, mannase and asparaginase have been successfully expressed at a high level in strains with a lower endogenous protein background [13, 14]. In another example, Kamaruddin et al. [15] increased the yield of cutinase by 36 -fold in A. niger by down-regulating the protease expression.

Acidic lipases are in a category of extreme enzymes that are stable and exhibit high catalytic activity in extreme acidic conditions. Due to the acidogenic properties of $A$. niger, most of the proteins or metabolites in $A$. niger are acid-tolerant. The $A$. niger lipase (ANL) is an acidic lipase that maintains high activity under acidic conditions and has a wide range of applications in food and chemical industries [16]. ANL has exhibited better resistance to acidic conditions compared to the other Aspergillus sp. lipases $[17,18]$. For example, the lipase from $A$. carneus was not stable at pH 6 as its optimum $\mathrm{pH}$ was 9.0 [17], and the highest stability of the lipase from $A$. awamori was at $\mathrm{pH}$ 8.0-9.0 [18]. However, the high cost for the production of the acidic $A$. niger lipase remains a barrier for its industrial applications. At present, ANL has been heterologously expressed in Escherichia coli and Pichia pastoris. The specific activity of the ANL was $110 \mathrm{U} /(\mathrm{mg}$ protein) in E. coli and could be improved two folds by addition of $\mathrm{Ca}^{2+}$ [19]. When expressed in $P$. patoris the activity of ANL fused with a small ubiquitin-related modifier (SUMO) reached $173 \mathrm{U} /$ (ml supernatant) and $432 \mathrm{U} /(\mathrm{mg}$ protein) in the shake flasks [20].

In this study, the ANL gene was homologously expressed in A. niger. Improvement of the A. niger lipase (ANL) expression was achieved through three strategies, including the addition of Kozak sequences for enhancing the translation efficiency, the expression of the native ANL with the introns for improving the stability of the mRNA, and optimization of signal sequences for enhancing the efficiency of extracellular secretion.

\section{Materials and Methods}

\section{Strains, Plasmids, Media and Culture Conditions}

E. coli TOP10 was used to maintain and amplify the plasmids. A. niger 89 was preserved in our lab and used as the expression host, as it has a low-background of endogenous secretory proteins and is hygromycin B-sensitive. Agrobacterium tumefaciens AGL1 was used for $A$. tumefaciens-mediated transformation (ATMT).

LB medium ( $1 \% \mathrm{w} / \mathrm{v}$ peptone, $0.5 \% \mathrm{w} / \mathrm{v}$ yeast extract, $1 \% \mathrm{w} / \mathrm{v}$ $\mathrm{NaCl}$ with $50 \mu \mathrm{g} / \mathrm{ml}$ kanamycin) was used for cultivation of $E$. coli. YEB medium $(0.1 \% \mathrm{w} / \mathrm{v}$ yeast extract, $0.5 \% \mathrm{w} / \mathrm{v}$ peptone,
$0.5 \% \mathrm{w} / \mathrm{v}$ beef extract, $0.5 \% \mathrm{w} / \mathrm{v}$ sucrose, $0.0493 \% \mathrm{w} / \mathrm{v}$ $\mathrm{MgSO}_{4} \cdot 7 \mathrm{H}_{2} \mathrm{O}$, pH 7.0 with $50 \mu \mathrm{g} / \mathrm{ml}$ Rif ) was used for the $A$. tumefaciens growth at $28^{\circ} \mathrm{C} 200 \mathrm{rpm}$ for $12-16 \mathrm{~h}$. IM medium $\left(0.145 \% \mathrm{w} / \mathrm{v} \mathrm{KH} \mathrm{PO}_{4}, 0.205 \% \mathrm{w} / \mathrm{v} \mathrm{K} \mathrm{HPO}_{4}, 0.05 \% \mathrm{w} / \mathrm{v}\left(\mathrm{NH}_{4}\right)_{2} \mathrm{SO}_{4}\right.$, $0.05 \% \mathrm{w} / \mathrm{v} \mathrm{MgSO}_{4} \cdot 7 \mathrm{H}_{2} \mathrm{O}, 0.015 \% \mathrm{w} / \mathrm{v} \mathrm{NaCl}, 0.0066 \% \mathrm{w} / \mathrm{v} \mathrm{CaCl}_{2}$, $0.000248 \% \mathrm{w} / \mathrm{v} \mathrm{FeSO}_{4} \cdot 7 \mathrm{H}_{2} \mathrm{O}, 0.18 \% \mathrm{w} / \mathrm{v}$ glucose, $0.5 \% \mathrm{v} / \mathrm{v}$ glycerin with $40 \mathrm{mM}$ MES (pH5.3) and $200 \mu \mathrm{M}$ Acetosyringone (AS)) was used for pre-incubation of A. tumefaciens at $28^{\circ} \mathrm{C}$ $200 \mathrm{rpm}$ and IM medium supplemented with $2 \%$ agar (IM plate) was used for co-cultivation of $A$. tumefaciens and $A$. niger at $23^{\circ} \mathrm{C}$. The potato dextrose agar (PDA plate, OKA Co. Ltd., China) was used for sporulation of $A$. niger. Fermentation medium $(0.2 \% \mathrm{w} / \mathrm{v}$ $\mathrm{NaNO}_{3}, 0.05 \% \mathrm{w} / \mathrm{v} \mathrm{KCl}, 0.05 \% \mathrm{w} / \mathrm{v} \mathrm{MgSO}_{4} \cdot 7 \mathrm{H}_{2} \mathrm{O}, 0.1 \% \mathrm{w} / \mathrm{v}$ $\mathrm{K}_{2} \mathrm{HPO}_{4} \cdot 3 \mathrm{H}_{2} \mathrm{O}, 0.001 \% \mathrm{w} / \mathrm{v} \mathrm{FeSO} \cdot 7 \mathrm{H}_{2} \mathrm{O}, 1 \% \mathrm{w} / \mathrm{v}\left(\mathrm{NH}_{4}\right)_{2} \mathrm{SO}_{4}, 4 \%$ $\mathrm{w} / \mathrm{v}$ corn starch, $2 \% \mathrm{v} / \mathrm{v}$ olive oil, $10 \% \mathrm{v} / \mathrm{v} 10 \times 100 \mathrm{mmol} / \mathrm{l} \mathrm{pH}$ 6.0 phosphate buffer) was used for the protein expression in A. niger. The rhodamine-olive oil plate $\left(0.2 \% \mathrm{w} / \mathrm{v} \mathrm{NaNO}_{3}, 0.05 \%\right.$ $\mathrm{w} / \mathrm{v} \mathrm{KCl}, 0.05 \% \mathrm{w} / \mathrm{v} \mathrm{MgSO}_{4} \cdot 7 \mathrm{H}_{2} \mathrm{O}, 0.1 \% \mathrm{w} / \mathrm{v} \mathrm{K}_{2} \mathrm{HPO}_{4} \cdot 3 \mathrm{H}_{2} \mathrm{O}$, $0.25 \% \mathrm{w} / \mathrm{v}$ glucose, $0.25 \% \mathrm{w} / \mathrm{v}$ corn starch, $0.25 \% \mathrm{w} / \mathrm{v}$ maltose, $10 \% \mathrm{v} / \mathrm{v} 10 \times 100 \mathrm{mmol} / \mathrm{l} \mathrm{pH} 6.0$ phosphate buffer, $1^{*} 10^{-3} \% \mathrm{w} / \mathrm{v}$ Rhodamine B (Biosharp Co. Ltd., China), 1\% v/v olive oil emulsion (olive oil was emulsified with $4 \% \mathrm{w} / \mathrm{v}$ polyvinyl alcohol (PVA) in a ratio of 1:3 (v/v) by a high-speed homogenizer), $2 \%$ $\mathrm{w} / \mathrm{v}$ agar) was used for screening.

\section{Construction of Recombinant Strains}

The full-length gene of ANL (ANL1000) (GenBank: DQ647700.1) contains three introns. ANL1000 was amplified from the $A$. niger genome and the intron-free $A N L$ gene $(A N L)$ was amplified by overlap extension PCR. In the plasmid pCAMglaS-ANL, the intron-free $A N L$ gene was fused with the glaA signal sequence and expressed under the gpdA promoter. The $A N L$ gene in pCAMglaSANL was replaced with ANL1000 by restriction enzyme digestion (ApaI and BamHI) to construct the plasmid pCAMglaS-ANL1000 (Fig. 1). Three kinds of signal sequences were used, those of glucoamylase, ANL and exoglucanase cbhI. The signal sequences were introduced through PCR. Six vectors were constructed with different combinations of the three signal sequences and two lengths of $A$. niger lipase gene (ANL, ANL1000). According to the design principle of the kozak sequence [21], the kozak sequence $\left(\mathrm{GCCA}^{-3} \mathrm{CCA}^{+1} \mathrm{TGG}^{+4}\right)$ was added around the start codon $\mathrm{A}^{+1} \mathrm{TG}$, and two other nucleotides were added downstream of the Kozak sequence to avoid frameshift. As indicated in Table S3, the other two added nucleotides are AT for the glaA signal and AG for the $A N L$ signal and the $c b h I$ signal right after the $\mathrm{G}^{+4}$. All plasmids contained the Hyg marker gene for selection on hygromycin B. $6 \times$ his-tag was added at the C-terminus of the lipase for purification of the expressed enzyme by affinity chromatography. The work flow for construction of the plasmids is shown in Fig. 2. All primers used are listed in Table S1. All vectors proved to be correctly assembled by restriction endonuclease digestion and sequencing of the assembly joint. 


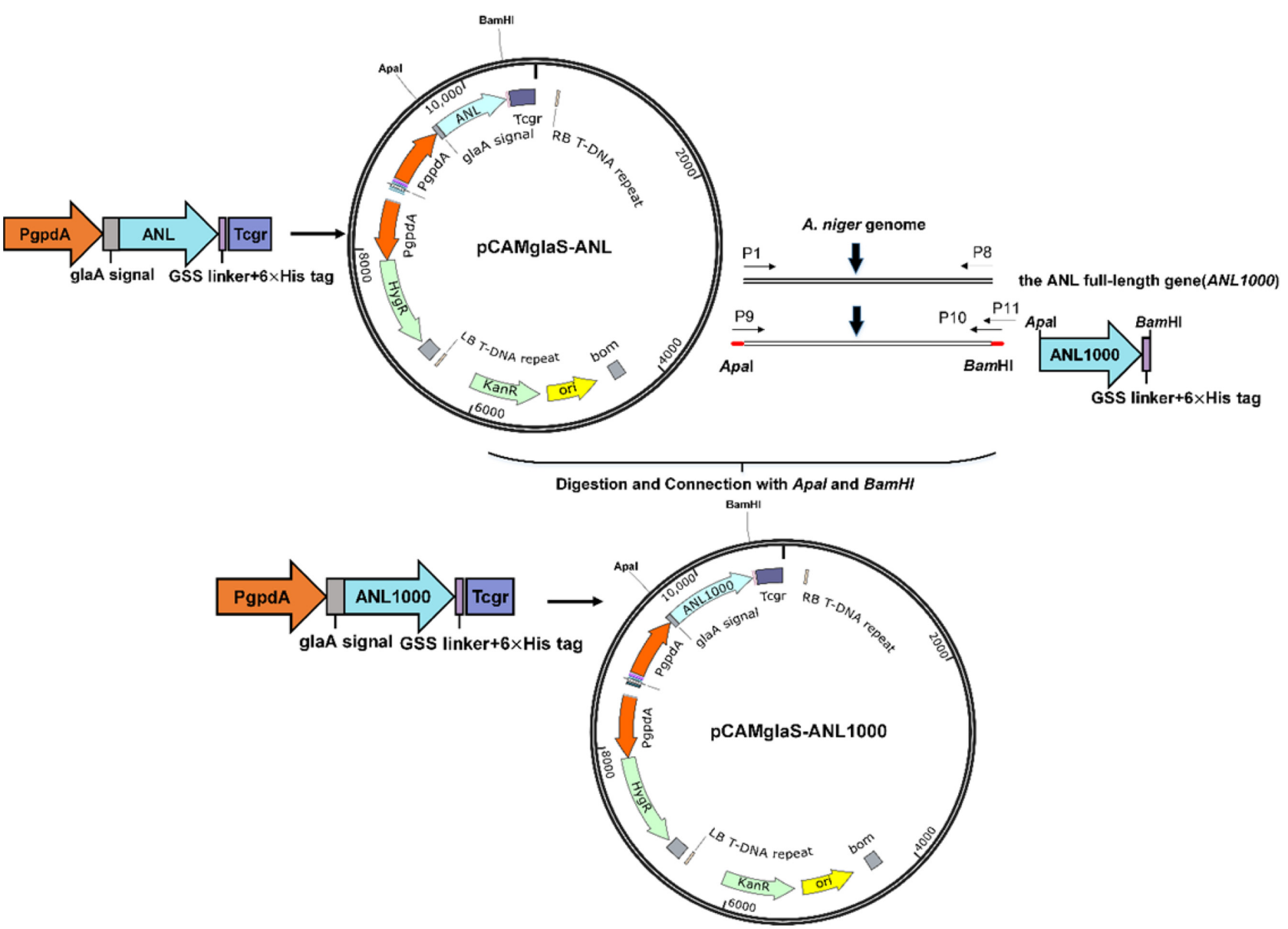

Fig. 1. Construction of pCAMglaS-ANL and pCAMglaS-ANL1000 expression vectors.

\section{Agrobacterium-Mediated Transformation (ATMT)}

In the recombinant plasmid the fragment including the target gene between two elements, RB (right boundary) and LB (left boundary), was randomly inserted into the genome of $A$. niger by ATMT. The recombinant plasmids were transformed into $A$. tumefaciens AGL1 by the freeze-thaw method [22]. Positive transformants of AGL1 were cultivated in $5 \mathrm{~mL}$ of YEB at $28^{\circ} \mathrm{C}$ for $16 \mathrm{~h}$, and then collected and incubated in IM liquid medium at $28^{\circ} \mathrm{C}$ to an $\mathrm{OD}_{600}$ of $0.8-1.0$. A. niger spore suspension was generated from strains cultivated for $3-5$ days at $30^{\circ} \mathrm{C}$. A mixture of $100 \mu \mathrm{l}$ of the $A$. niger spore suspension $\left(10^{7}\right.$ spores $\left./ \mathrm{ml}\right)$ and $100 \mu \mathrm{l}$ of the positive transformant of AGL1 was spread on the cellophane covering the IM plates. The co-cultivation was carried out in the dark at $23^{\circ} \mathrm{C}$ for $48 \mathrm{~h}$. Afterwards, the cellophane was transferred to the PDA plates with hygromycin B $(200 \mu \mathrm{g} / \mathrm{ml})$ and cefotaxime sodium $(200 \mu \mathrm{g} / \mathrm{ml})$. The plates were incubated at $30^{\circ} \mathrm{C}$ for 2-3 $\mathrm{d}$. Then, the transformants were rescreened on the PDA plates with hygromycin B $(200 \mu \mathrm{g} / \mathrm{ml})$. The transformants were purified by spore isolation for at least three successive generations on the PDA plates with hygromycin B $(200 \mu \mathrm{g} / \mathrm{ml})$.
The positive transformants were confirmed by PCR with the identification primers (Table S2).

\section{Expression of ANL in A. niger}

The wild-type strain and the positive transformants of $A$. niger were grown on the PDA plates for 3-5 d, and then the spores were washed with saline. The spore suspension was inoculated into $50 \mathrm{ml}$ fermentation medium with a final concentration of $2 \times 10^{5}$ spores $/ \mathrm{ml}$ in $250 \mathrm{ml}$ flasks shaken $(200 \mathrm{rpm})$ at $28^{\circ} \mathrm{C}$ for $168 \mathrm{~h}$. Protein concentrations of the supernatant were determined by the Bradford method [23].

\section{Purification and Identification of ANL}

ANL fused with a $6 \times$ his-tag at the C-terminus was purified by Ni-NTA column affinity chromatography using the ÄKTA protein purification system. The fermentation supernatants were collected by filtering through a 200-mesh nylon membrane, then filtered through $0.22 \mu \mathrm{m}$ aqueous microfiltration membrane. The system was equilibrated with buffer A $(150 \mathrm{mM} \mathrm{NaCl}, 20 \mathrm{mM}$ Tris- $\mathrm{HCl}$, $\mathrm{pH}$ 8.0) and the target protein was eluted with buffer B (150 mM 


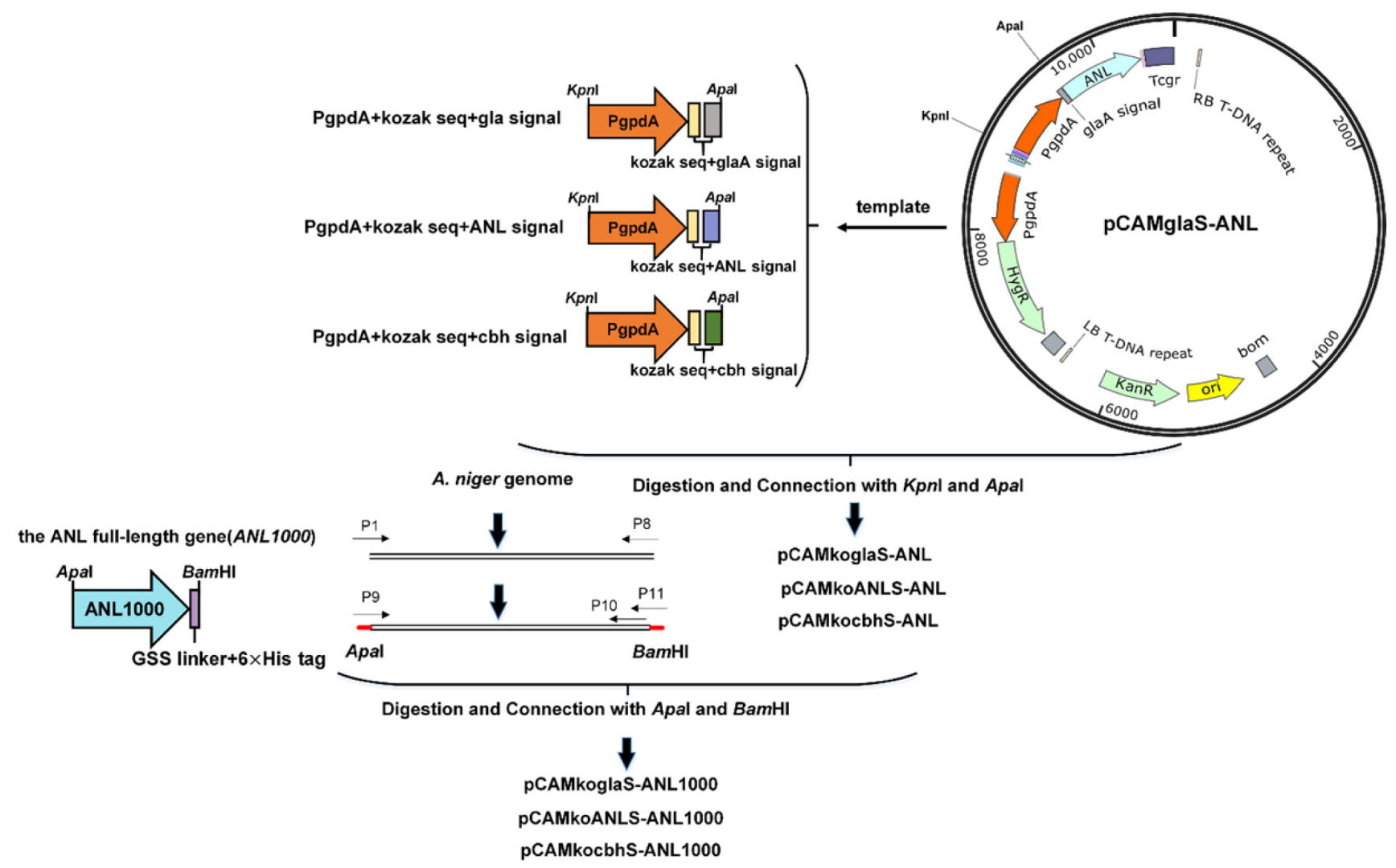

Fig. 2. Construction of 6 kinds of expression vectors.

$\mathrm{NaCl}, 20 \mathrm{mM}$ Tris- $\mathrm{HCl}, 0.5 \mathrm{M}$ imidazole, $\mathrm{pH}$ 8.0). The purified protein was examined by SDS-PAGE and stored in buffer $\mathrm{A}$ at $-80^{\circ} \mathrm{C}$ for further analysis. For preparation of the SDS-PAGE samples, the purified protein solution or the fermentation supernatant was mixed with the $2 X$ SDS loading buffer in equal volume. The samples were boiled for $10 \mathrm{~min}$, centrifuged for $5 \mathrm{~min}$, and then $10 \mu \mathrm{l}$ of each sample was loaded into the SDS-PAGE gel.

Matrix-Assisted Laser Desorption/Ionization Time-of-Flight Mass Spectrometry (MALDI-TOF-MS) was used for protein identification. The target protein on SDS-PAGE was cut out and digested. The peptide mass fingerprinting of the target protein was analyzed using Mascot software (http:/ /www.matrixscience.com).

\section{Assay of Enzyme Activity}

The enzyme activity of ANL was determined by alkali titration using olive oil as the substrate. Olive oil was emulsified with $4 \%$ $\mathrm{w} / \mathrm{v}$ polyvinyl alcohol (PVA) at a ratio of 1:3 (v/v) by a highspeed homogenizer and used as the substrate. Each reaction contained $4 \mathrm{ml}$ of substrate and $5 \mathrm{ml}$ of $50 \mathrm{mM}$ citrate-phosphate buffer ( $\mathrm{pH} 3.0$ ) and $1 \mathrm{ml}$ enzyme solution. For measurement of the purified enzyme, the activity assays were done using $1 \mathrm{ml}$ of $0.25 \mathrm{mg} / \mathrm{ml}$ enzyme solution. For measurement of the activity of the supernatant, the activity assays were done using $1 \mathrm{ml}$ of the supernatant. The reaction was incubated at $45^{\circ} \mathrm{C}$ for $15 \mathrm{~min}$, and then terminated by adding $15 \mathrm{ml}$ of $95 \%$ ethanol solution. The heat-inactivated enzyme solution was used as the blank control. The reaction solution was titrated with $0.1 \mathrm{~mol} / 1 \mathrm{NaOH}$ standard solution. The amount of enzyme that produces $1 \mu \mathrm{mol}$ of fatty acid in one minute is defined as one unit of enzyme activity. The enzyme activity was calculated using the following equation.

$$
X=\frac{(B-A) \times C \times n}{t}
$$

X: enzyme activity, U/L; B: volume of $\mathrm{NaOH}$ consumed by titrating the sample, ml; A: volume of $\mathrm{NaOH}$ consumed by titrating the blank; $\mathrm{C}: \mathrm{NaOH}$ concentration, $\mathrm{mol} / \mathrm{L}$; $\mathrm{n}$ : dilution factor; t: reaction time.

\section{Characterization of the Purified Enzyme ANL}

The optimum $\mathrm{pH}$ of the purified enzyme ANL was determined by measuring the lipase activity at $45^{\circ} \mathrm{C}$ in various $50 \mathrm{mM}$ citratephosphate buffers ( $\mathrm{pH}$ 2.0-9.0). The $\mathrm{pH}$ stability was studied by incubating the purified enzyme ANL in different $50 \mathrm{mM}$ citratephosphate buffers with $\mathrm{pH}$ ranging from 2.0 to 10.0 for $24 \mathrm{~h}$ at $45^{\circ} \mathrm{C}$. The samples were taken at 2 -h intervals for the first $12 \mathrm{~h}$ and for the last timepoint at $24 \mathrm{~h}$. The residual activity was then assayed under the standard assay conditions.

The optimum temperature of the purified enzyme ANL was 
determined by measuring the enzyme activity at various temperatures $\left(25^{\circ} \mathrm{C}-60^{\circ} \mathrm{C}\right)$ in $50 \mathrm{mM}$ of citrate-phosphate buffer, $\mathrm{pH}$ 3. The thermal stability was determined by incubating the purified enzyme ANL for $24 \mathrm{~h}$ at the desired temperatures $\left(30^{\circ} \mathrm{C}\right.$ $60^{\circ} \mathrm{C}$ ) followed by measuring the residual activity. The samples were taken at 2-h intervals for the first $12 \mathrm{~h}$ and for the last timepoint at $24 \mathrm{~h}$.

The kinetic parameters of ANL were determined using the emulsified triglyceride olive oil $(0-120 \mathrm{~g} / \mathrm{l})$ as the substrate and assayed using the alkali titration method under optimum assay conditions. The values of the kinetic parameters $K_{\mathrm{m}}$ and $k_{\text {cat }}$ were determined by Lineweaver-Burk plot and Michaelis-Menten equation.

\section{Results and Discussion}

\section{Design of the Expression Vectors}

The expression cassettes of the plasmids are shown in Table 1. ANL is the cDNA gene without intron, and ANL1000 represents the native full-length $A N L$ gene containing three introns. The length of the native $A N L$ gene is about 1,000 bp. Thus, we named the native $A N L$ 'ANL1000.' The Kozak sequence $\left(\mathrm{GCCA}^{-3} \mathrm{CCA}^{+1} \mathrm{TGG}^{+4}\right)$ was added around the start codon of the ANL gene in the plasmid pCAMkoglaSANL, and two other nucleotides were added downstream of the kozak sequence $\mathrm{G}^{+4}$ to form a codon to avoid frameshift. Three signal sequences were selected including the glucoamylase (glaA) signal sequence, the $A N L$ signal sequence and the cellobiohydrolase I $(c b h I)$ signal sequence for the expression of $A N L$ in $A$. niger. The glaA signal sequence is used widely in $A$. niger, because glucoamylase is expressed in high amounts in A. niger [24], and the signal sequence from a highly expressed gene usually helps the extracellular expression of the target gene [25]. The ANL signal sequence is its own signal sequence. Zoglowek et al. [8] suggest that natural signal sequence may be more suitable for gene expression than other signal sequences. The cbhI signal sequence was also used frequently in $A$. niger. In the study of Madhavan et al. [26], the cbhI signal sequence exhibited higher secretion than the glaA signal sequence. The signal sequences are listed in Table S3.

\section{Expression of ANL in A. niger}

Identification of positive transformants. We isolated several A. niger strains from the environment. The endogenous secretory proteins in the supernatant were detected on SDS-PAGE and we found that the secretory proteins in A. niger 89 were much lower than those in other strains (data not shown). Thus, we chose A. niger 89 as the expression host in our study. The plasmids indicated in Table 1 were transformed into A. niger 89 by ATMT for the expression of ANL. The positive transformants verified by PCR were plated on the rhodamine-olive oil plate as shown in Fig. 3. The lipase produced by the transformant can hydrolyze olive oil to generate fatty acids. The fatty acids then react with rhodamine $B$ to develop a red color under natural light and to emit fluorescence under ultraviolet light [27]. The larger the color halo around the colony, the higher the lipase activity. Thus, the positive transformants with higher lipase activity were selected according to the size of the color halo. The wild-type A. niger 89 didn't show an obvious color halo. The other 8 kinds of transformants showed different sizes of color halos on the rhodamineolive oil plates. Although transformed with the same plasmid, the expression level of lipase varied among different transformants due to the random insertion of the expression cassette in the genome [26].

The effects of the introns, the Kozak sequence and the signal sequences on the ANL expression. The wild-type strain $A$. niger 89 and the transformants were cultivated using corn starch and olive oil as the main carbon sources. Olive oil was used both for the carbon source and the inducer of the lipase. We followed the lipase production during fermentation. The lipase began to secrete into the medium between $48 \mathrm{~h}$ and $72 \mathrm{~h}$ and the highest lipase production was reached at around $168 \mathrm{~h}$ during the fermentation. The wild-type strain $A$. niger 89, the

Table 1. Plasmids used for the acidic lipase expression.

\begin{tabular}{llll}
\hline & \multicolumn{1}{c}{ Plasmid } & Transformants & \multicolumn{1}{c}{ Expression cassette } \\
\hline 1 & pCAMglaS-ANL & glaS-ANL & PgpdA- glaA signal-ANL-his tag-Tcgr \\
2 & pCAMglaS-ANL1000 & glaS-ANL1000 & PgpdA-glaA signal-ANL1000- his tag-Tcgr \\
3 & pCAMkoglaS-ANL & koglaS-ANL & PgpdA-Kozak seq-glaA signal-ANL- his tag-Tcgr \\
4 & pCAMkoANLS-ANL & koANLS-ANL & PgpdA-Kozak seq-ANL signal-ANL- his tag-Tcgr \\
5 & pCAMkocbhS-ANL & kocbhS-ANL & PgpdA-Kozak seq-cbhI signal-ANL- his tag-Tcgr \\
6 & pCAMkoglaS-ANL1000 & koglaS-ANL1000 & PgpdA-Kozak seq-glaA signal-ANL1000- his tag-Tcgr \\
7 & pCAMkoANLS-ANL1000 & koANLS-ANL1000 & PgpdA-Kozak seq-ANL signal-ANL1000- his tag-Tcgr \\
8 & pCAMkocbhS-ANL1000 & kocbhS-ANL1000 & PgpdA-Kozak seq-cbhI signal-ANL1000- his tag-Tcgr \\
\hline
\end{tabular}



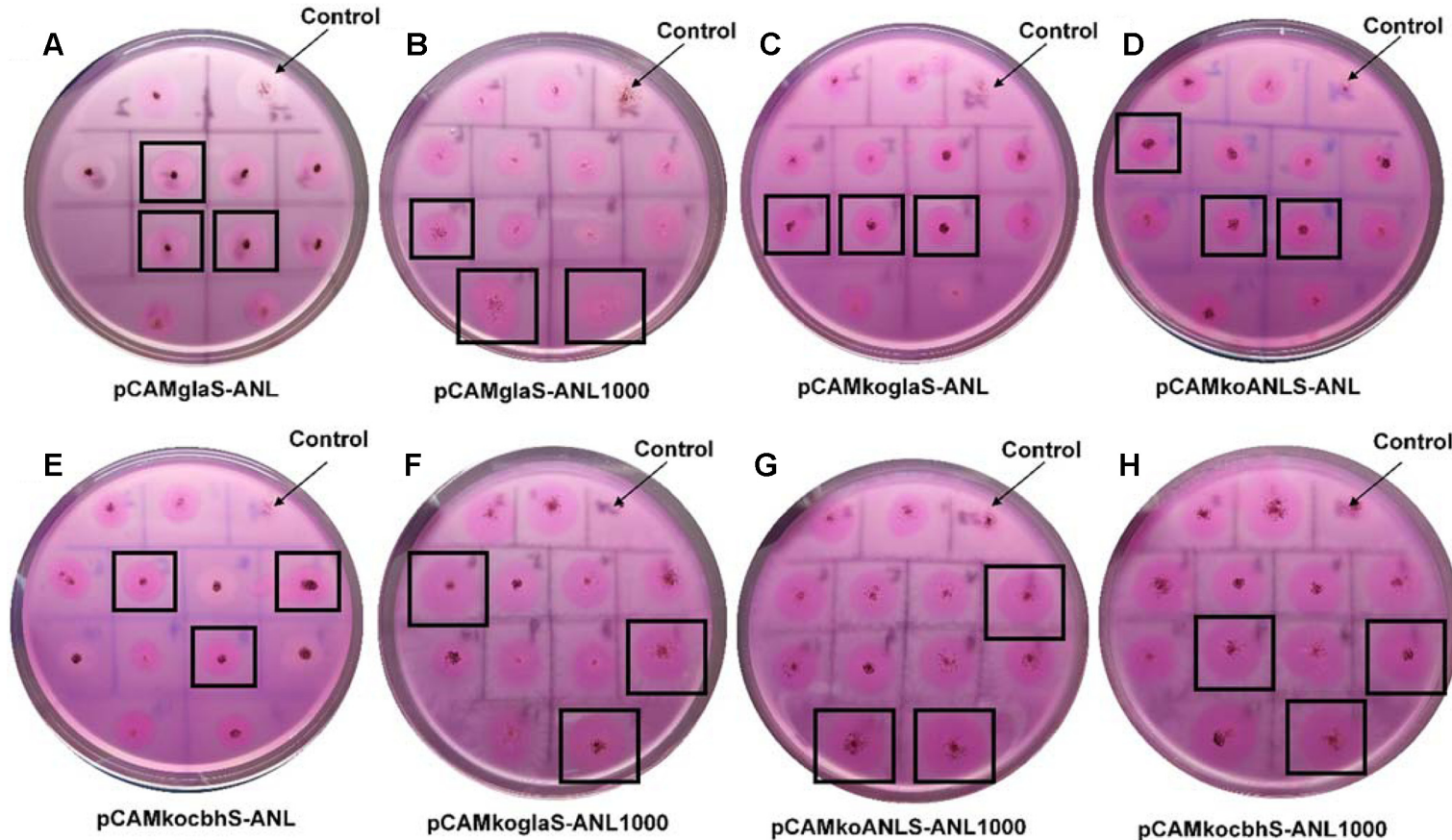

pCAMglaS-ANL1000
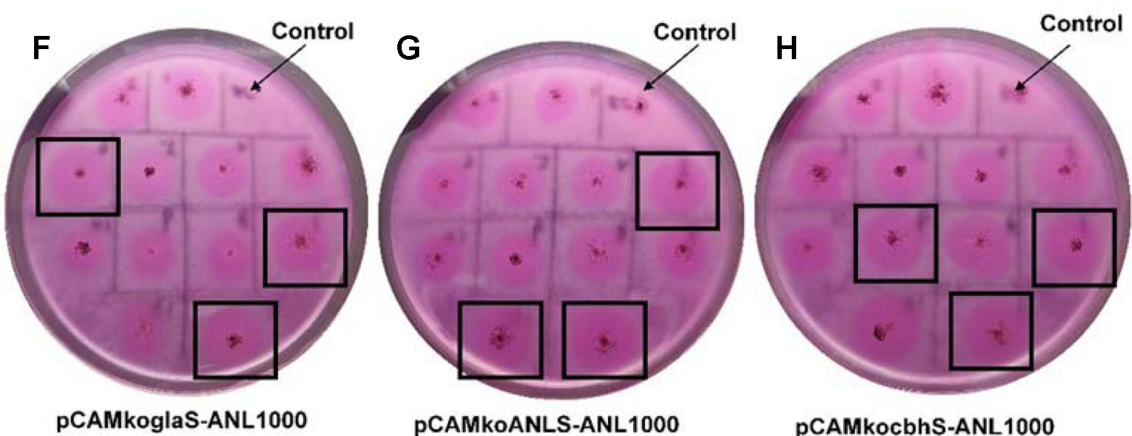

Fig. 3. A. niger 89 transformed with eight different plasmids grown on the rhodamine-olive oil plates for 2 days (the wild-type A. niger 89 as the control).

The letters represent 8 different constructs. The bigger the red halo, the higher the lipase activity. To determine the lipase activity shown in Fig. 4 we selected three transformants for each construct with relatively bigger halos indicated with a square.

transformants of pCAMglaS-ANL and pCAMglaS-ANL1000 were characterized for the effect of the introns. As shown in Fig. $4 \mathrm{~A}$, there was no obvious target band for either the wild type (A. niger 89 ) or the transformants of pCAMglaSANL (glaS-ANL). The target band for the transformant of pCAMglaS-ANL1000 with the introns (glaS-ANL1000) could be detected and the lipase activity in the supernatant reached $75.80 \mathrm{U} / \mathrm{ml}$. Although introns do not participate in protein-coding sequences, they do play significant functional roles in eukaryotes, including regulation of alternative splicing, positive regulation of gene expression, regulation of nonsense-mediated decay, and provision of a new gene source as well as impact on natural selection [28]. In our case, the presence of the introns may enable a more stable secondary structure, which protects pre-mRNA from degradation in the nucleus $[29,30]$. Moreover, the introns can assist in the transport of pre-mRNA [31] and regulation of mRNA maturation [32]. In this study, the expression of the $A N L$ gene with introns was significantly higher compared to the cDNA.

The effect of the Kozak sequence on the lipase expression was also evaluated using two sets of comparison (pCAMglaS-ANL vs pCAMkoglaS-ANL, pCAMglaS-ANL1000 vs pCAMkoglaS-ANL1000). After addition of the kozak sequence in pCAMkoglaS-ANL, the lipase activity increased from undetectable to $61.30 \mathrm{U} / \mathrm{ml}$. When the Kozak sequence was added in pCAMkoglaS-ANL1000 with the introns, the lipase activity was improved by 1.33 -fold compared with that of pCAMglaS-ANL1000.

Kozak et al. [21] found that the base pair near the initiation codon has a certain effect in translation, and the

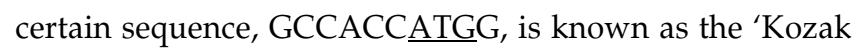
sequence' and shows a higher translation level. The Kozak sequence enhances the translation efficiency by optimization of the ATG environment to avoid the leaky ribosomalscanning [33]. The Kozak sequence has been applied to increase the expression level of foreign genes in mammalian cells [34, 35] and Saccharomyces cerevisiae [36], but there is no report on the effect of the Kozak sequence on protein expression in A. niger.

The effects of three signal sequences ( laA signal sequence, $A N L$ signal sequence and cbhI signal sequence) were analyzed and tested with both ANL1000 and ANL. As shown in Fig. 4 and Table 2, the enzyme production and protein concentration in the supernatant of the transformants were evaluated. The enzyme production in the supernatant 

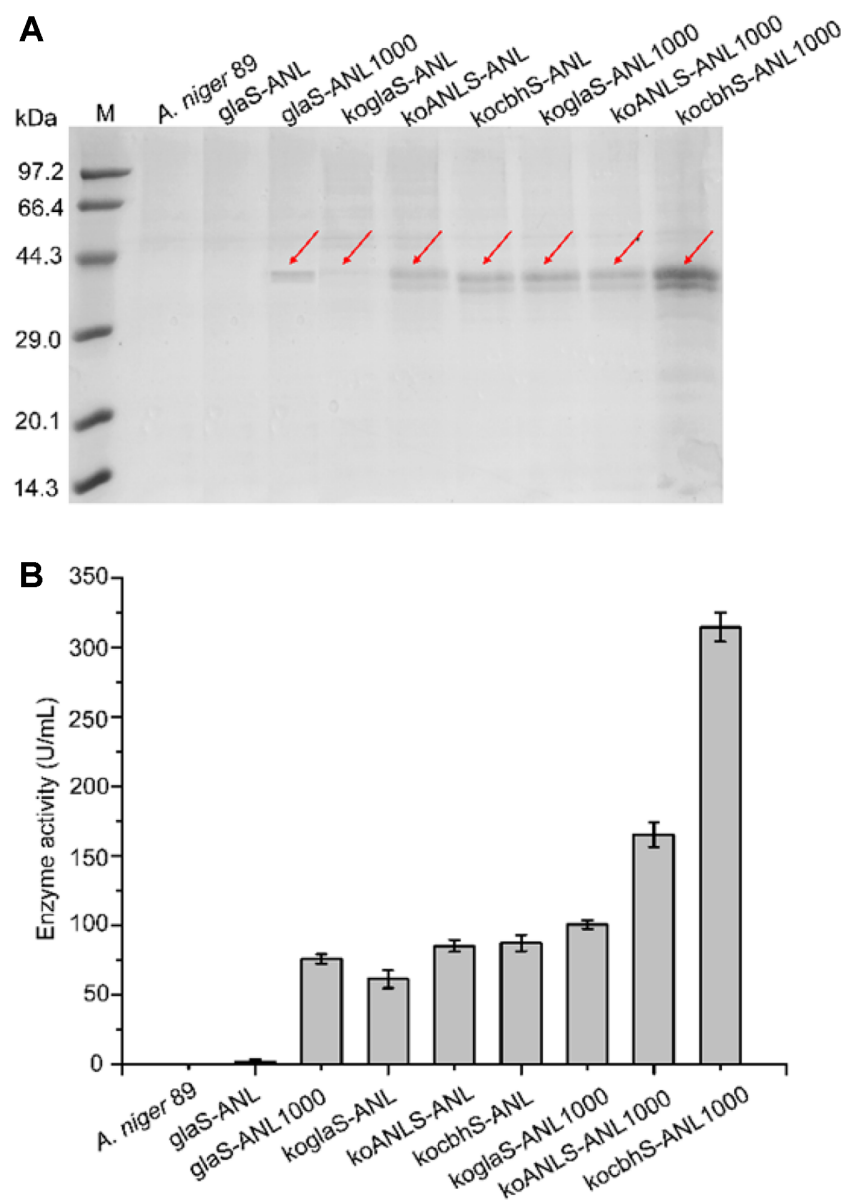

Fig. 4. SDS-PAGE and the lipase activities of the transformants. (A) SDS-PAGE of the fermentation supernatants after cultivation for 168 h. (B) Enzyme production in the supernatants after cultivation for $168 \mathrm{~h}$. The lipase activity was measured on emulsified olive oil at $\mathrm{pH}$ 3.0 and $45^{\circ} \mathrm{C}$. Error bars indicated the standard deviation of the enzyme activities of three transformants for each construct in biological triplicates.

has a positive correlation with the protein concentration. Higher enzyme activity per milliliter $(\mathrm{U} / \mathrm{ml})$ indicates higher enzyme production in the supernatant. The enzyme production of the pCAMkocbhS-ANL1000 transformant (kocbhS-ANL1000) was the highest $(314.67 \mathrm{U} / \mathrm{ml})$, followed by koANLS-ANL1000, koglaS-ANL1000, kocbhS-ANL, koANLS-ANL, glaS-ANL1000, koglaS-ANL, glaS-ANL. The enzyme production of all ANL1000 proteins was higher compared to ANL. Regarding the signal sequence, the transformants with the $c b h I$ signal sequence showed the highest expression, followed by those with the ANL and glaA signal sequence. It is worth noting that the thickness of the protein bands on SDS-PAGE was not correlated very well with the average protein concentration in Table 2. The
Table 2. Protein concentration in the supernatant of the transformants after cultivation for $168 \mathrm{~h}$.

\begin{tabular}{lc}
\hline \multicolumn{1}{c}{ Transformants } & Protein concentration $(\mathrm{mg} / \mathrm{ml})^{*}$ \\
\hline A. niger 89 & $0.08 \pm 0.01$ \\
glaS-ANL & $0.09 \pm 0.01$ \\
glaS-ANL1000 & $0.14 \pm 0.02$ \\
koglaS-ANL & $0.12 \pm 0.01$ \\
koANLS-ANL & $0.18 \pm 0.02$ \\
kocbhS-ANL & $0.19 \pm 0.02$ \\
koglaS-ANL1000 & $0.20 \pm 0.01$ \\
koANLS-ANL1000 & $0.23 \pm 0.03$ \\
kocbhS-ANL1000 & $0.32 \pm 0.02$ \\
*The standard deviation indicates three biological replicates of three \\
transformants for each construct.
\end{tabular}

reason was that the loading sample for each construct was not a mixture of three transformants, but one randomly selected from these replicates.

\section{Purification and Identification of ANL}

As shown in Fig. 5 the fermentation supernatant and the purified enzyme were detected by SDS-PAGE. About $0.15 \mathrm{~g}$ of ANL enzyme was purified from $1 \mathrm{~L}$ fermentation supernatant. The specific activity of the purified ANL is $680.34 \pm 4.75 \mathrm{U} / \mathrm{mg}$. Two bands were detected for both the fermentation supernatant samples and the purified protein. The four bands of proteins were identified by MALDITOF-MS. The results showed that band-A and band-C

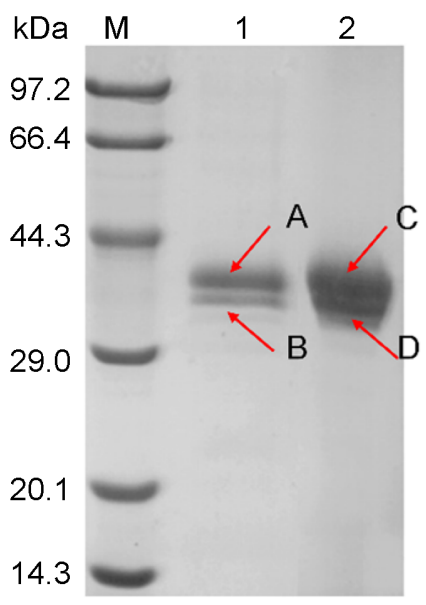

Fig. 5. SDS-PAGE of the fermentation supernatant and the purified protein.

1. The fermentation supernatant of kocbhS-ANL1000 after cultivation for $168 \mathrm{~h}$. 2. The purified protein loaded with $3 \mu \mathrm{g}$. Band A, B, C, and $\mathrm{D}$ were cut from gel and analyzed using MALDI-TOF-MS. 

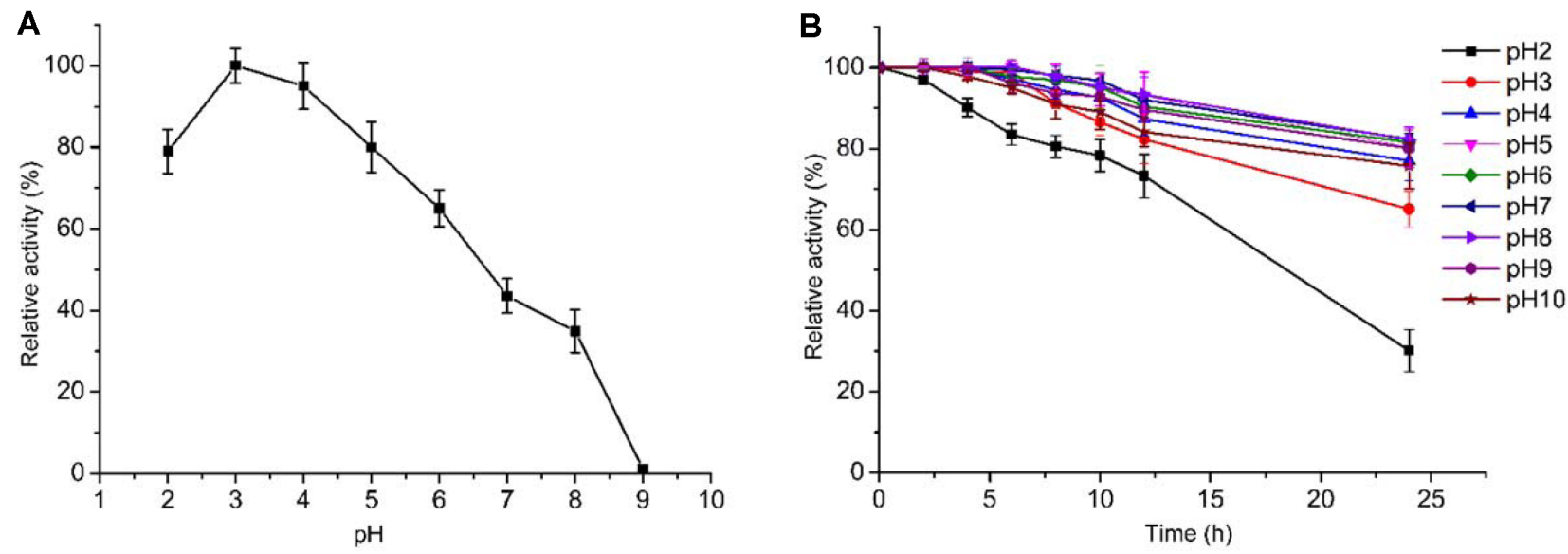

Fig. 6. Effect of $\mathrm{pH}$ on the activity and stability of ANL.

(A) The optimal $\mathrm{pH}$. The activity was determined at $\mathrm{pH} 2.0-9.0$ and $45^{\circ} \mathrm{C}$ using olive oil as the substrate. (B) The $\mathrm{pH}$ stability of ANL. The $\mathrm{pH}$ stability of ANL was determined at $45^{\circ} \mathrm{C}$ and $\mathrm{pH} 3.0$ after being incubated in $\mathrm{pH}$ 2.0-10.0 $50 \mathrm{mM}$ citrate-phosphate buffer for up to $24 \mathrm{~h}$. Error bars indicate the standard deviation of three biological replicates.

contained four unique fragments of VTHLNDIVPR, VGNYALAEHITSQGSGANFR, MLLEFDLTNNFGGTAGF LAADNTNKR and NDGYSVELYTYGCPR, the band-B and the band-D contained two unique fragments of VGNYALAEHITSQGSGANFR and VTHLNDIVPR. By comparison, all these unique fragments belong to ANL. The difference in size may be due to post-translational modifications such as glycosylation.

\section{Enzymatic Characterization}

Effects of $\mathrm{pH}$ on the lipase activity and stability. As shown in Fig. 6A the optimum $\mathrm{pH}$ of ANL is $\mathrm{pH}$. ANL exhibits a high stability in a broad range of $\mathrm{pH}$ from 3 to 10 . After being retained under $\mathrm{pH} 3$ for $24 \mathrm{~h}$, the relative activity of ANL is still more than $60 \%$ (Fig. 6B). In other reports the optimum $\mathrm{pH}$ of ANL was around 2.5-5 [37-39]. During fermentation $A$. niger produces a high amount of acid, which might be the reason for a very acid-resistant ANL.

Effects of temperature on the lipase activity and stability. As shown in Fig. 7 the optimum temperature of ANL is $45^{\circ} \mathrm{C}$. In the analysis of thermostability, the relative activity of the purified ANL was still more than $70 \%$ after incubation at $30^{\circ} \mathrm{C}$ and $40^{\circ} \mathrm{C}$ for $24 \mathrm{~h}$. However, the relative
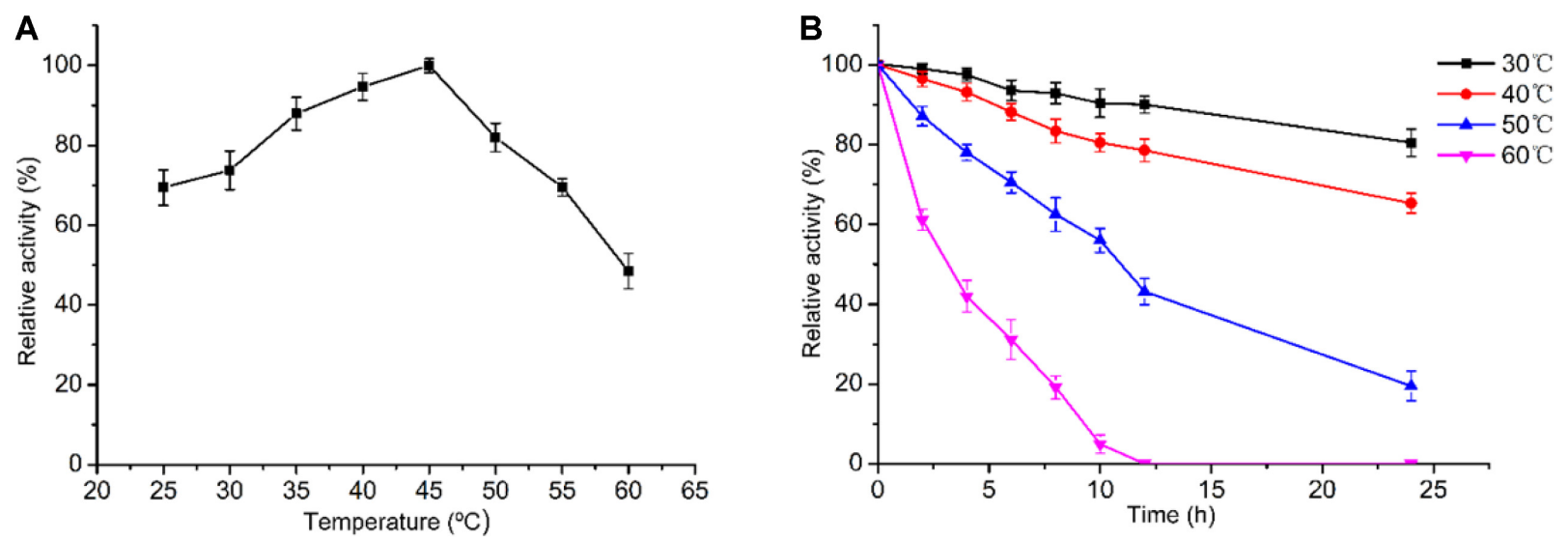

Fig. 7. Effect of temperature on the activity and stability of ANL.

(A) The optimal temperature. The activity was determined at $25-60^{\circ} \mathrm{C}$ and $\mathrm{pH}$ 3.0. (B) The temperature stability of ANL. The temperature stability of ANL was determined at $45^{\circ} \mathrm{C}$ and pH 3.0 after incubation for up to $24 \mathrm{~h}$ at temperatures of $30-60^{\circ} \mathrm{C}$. Error bars indicate the standard deviation of three biological replicates. 
Table 3. The kinetic parameters of ANL.

\begin{tabular}{cccc}
\hline Lipase & $K_{\mathrm{m}}(\mathrm{g} / \mathrm{l})$ & $k_{\text {cat }}(1 / \mathrm{s})$ & $k_{\text {cat }} / K_{\mathrm{m}}(\mathrm{L} /(\mathrm{s} \mathrm{g}))$ \\
\hline ANL & $9.30 \pm 1.04$ & $391.66 \pm 8.69$ & $42.25 \pm 3.35$ \\
\hline
\end{tabular}

activity decreased significantly when incubated at $50^{\circ} \mathrm{C}$ for $12 \mathrm{~h}$. At $60^{\circ} \mathrm{C}$ the relative activity dropped to $30 \%$ within 5 $\mathrm{h}$ and was completely inactivated within $12 \mathrm{~h}$.

Determination of kinetic parameters. The olive oil emulsion was used as the substrate to determine the kinetic parameters. As shown in Table 3, the $K_{\mathrm{m}}$ and $k_{\text {cat }}$ values are $9.30 \pm 1.04 \mathrm{~g} / 1$ and $391.66 \pm 8.69 \mathrm{~s}^{-1}$, respectively. $K_{\mathrm{m}}$ reflects the affinity of the enzyme to the substrate. The lower the $K_{\mathrm{m}}$, the higher the affinity with the substrate. In this study, ANL has a better affinity towards olive oil compared with other studies in which the $K_{\mathrm{m}}$ values of the lipases from $A$. niger were $77 \mathrm{mM}(22 \mathrm{~g} / 1)$ [39] and $108 \mathrm{~g} / 1$ [16] using olive oil as the substrates.

\section{Acknowledgements}

Financial support from the National Natural Science Foundation of China (31671799), Six Talent Peaks Project in Jiangsu Province (NY-010), the National First-Class Discipline Program of Light Industry Technology and Engineering (LITE2018-09), and the National High Technology Research and Development Program of China (863 Program) (2012AA022207) is greatly appreciated.

\section{Conflict of Interest}

The authors have no financial conflicts of interest to declare.

\section{References}

1. Schuster E, Dunn-Coleman N, Frisvad JC, van Dijck PWM. 2002. On the safety of Aspergillus niger - A review. Appl. Microbiol. Biotechnol. 59: 426-435.

2. Cairns TC, Nai C, Meyer V. 2018. How a fungus shapes biotechnology: 100 years of Aspergillus niger research. Fungal Biol. Biotechnol. 5: 13.

3. Steiniger C, Hoffmann S, Mainz A, Kaiser M, Voigt K, Meyer V, et al. 2017. Harnessing fungal nonribosomal cyclodepsipeptide synthetases for mechanistic insights and tailored engineering. Chem. Sci. 8: 7834-7843.

4. Michael W, Cherry L, Victoria DC, Fox BP, Fox JA, Wong DL, et al. 2004. Characterization of humanized antibodies secreted by Aspergillus niger. Appl. Environ. Microbiol. 70: 2567-2576.
5. Punt PJ. 2002. Filamentous fungi as cell factories for protein production. Trends Biotechnol. 20: 200-206.

6. Magaña-Ortíz D, Fernández F, Loske AM, Gómez-Lim MA. 2018. Extracellular expression in Aspergillus niger of an antibody fused to Leishmania sp. antigens. Curr. Microbiol. 75: 40-48.

7. Guo Y, Zheng P, Sun J. 2010. Aspergillus niger as a potential cellular factory: prior knowledge and key technology. Sheng Wu Gong Cheng Xue Bao 26: 1410-1418.

8. Zoglowek M, Lübeck PS, Ahring BK, Lübeck M. 2015. Heterologous expression of cellobiohydrolases in filamentous fungi - an update on the current challenges, achievements and perspectives. Process Biochem. 50: 211-220.

9. Krasevec N, van de Hondel C, Komel R. 2000. Expression of human lymphotoxin alpha in Aspergillus niger. Pflugers Arch. 440: R83-R85.

10. Svetina M, Krasevec N, Gaberc-Porekar V, Komel R. 2000. Expression of catalytic subunit of bovine enterokinase in the filamentous fungus Aspergillus niger. J. Biotechnol. 76: 245-251.

11. Roberts IN, Jeenes DJ, Mackenzie DA, Wilkinson AP, Sumner IG, Archer DB. 1992. Heterologous gene expression in Aspergillus niger: a glucoamylase-porcine pancreatic prophospholipase A2 fusion protein is secreted and processed to yield mature enzyme. Gene 122: 155-161.

12. Zhang H, Yan JN, Zhang H, Qi LT, Xu Y, Zhang YY, et al. 2018. Effect of gpd box copy numbers in the gpdA promoter of Aspergillus nidulans on its transcription efficiency in A. niger. FEMS Microbiol. Lett. 1: 365.

13. Liu F, Wang B, Ye Y, Pan L. 2017. High level expression and characterization of tannase tan7 using Aspergillus niger $\mathrm{SH}-2$ with low-background endogenous secretory proteins as the host. Protein Expr. Purif. 144: 71-75.

14. Zhang H, Wang S, Zhang XX, Ji W, Song FP, Zhao Y, et al. 2016. The amyR-deletion strain of Aspergillus niger CICC2462 is a suitable host strain to express secreted protein with a low background. Microb. Cell Fact. 15: 11.

15. Kamaruddin N, Storms R, Mahadi NM, Illias RM, Abu Bakar FD, Murad AMA. 2018. Reduction of extracellular proteases increased activity and stability of heterologous protein in Aspergillus niger. Arab. J. Sci. Eng. 43: 3327-3338.

16. Zhang XF, Ai YH, Xu Y, Yu XW. 2019. High-level expression of Aspergillus niger lipase in Pichia pastoris: characterization and gastric digestion in vitro. Food Chem. 274: 305-313.

17. Saxena RK, Davidson WS, Sheoran A, Giri B. 2003. Purification and characterization of an alkaline thermostable lipase from Aspergillus carneus. Process Biochem. 39: 239-247.

18. Xia J-1, Huang B, Nie Z-y, Wang W. 2011. Production and characterization of alkaline extracellular lipase from newly isolated strain Aspergillus awamori HB-03. J. Cent. South Univ. 18: 1425.

19. Shu ZY, Yan YJ, Yang JK, Xu L. 2007. Aspergillus niger lipase: gene cloning, over-expression in Escherichia coli and in vitro refolding. Biotechnol. Lett. 29: 1875-1879. 
20. Yang J, Yan X, Zhang Z, Jiang X, Yan Y. 2009. Two-step synthesis of the full length Aspergillus niger lipase gene lipA leads to high-level expression in Pichia pastoris. Sheng $W u$ Gong Cheng Xue Bao 25: 381-387.

21. Kozak M. 1986. Point mutations define a sequence flanking the AUG initiator codon that modulates translation by eukaryotic ribosomes. Cell 44: 283-292.

22. Ahangarzadeh S, Daneshvar $\mathrm{MH}$, Rajabi-Memari $\mathrm{H}$, Galehdari H, Alamisaied K. 2012. Cloning, transformation and expression of human interferon $\alpha 2 b$ Gene in tobacco plant (Nicotiana tabacum cv. xanthi). Jundishapur J. Nat. Pharm. Prod. 7: 111-116.

23. Bradford MM. 1976. A rapid and sensitive method for the quantitation of microgram quantities of protein utilizing the principle of protein-dye binding. Anal. Biochem. 72: 248-254.

24. Xu Y, Wang YH, Liu TQ, Zhang H, Zhang H, Li J. 2018. The GlaA signal peptide substantially increases the expression and secretion of $\alpha$-galactosidase in Aspergillus niger. Biotechnol. Lett. 40: 949-955.

25. Li M, Zhou L, Liu M, Huang Y, Sun X, Lu F. 2013. Construction of an engineering strain producing high yields of alpha-transglucosidase via Agrobacterium tumefaciens-mediated transformation of Asperillus niger. Biosci. Biotechnol. Biochem. 77: 1860-1866.

26. Madhavan A, Pandey A, Sukumaran RK. 2017. Expression system for heterologous protein expression in the filamentous fungus Aspergillus unguis. Bioresour. Technol. 245:1334-1342.

27. Canseco-Pérez MA, Castillo-Avila GM, Chi-Manzanero B, Islas-Flores I, Apolinar-Hernández MM, Rivera-Muñoz G, et al. 2018. Fungal screening on olive oil for extracellular triacylglycerol lipases: selection of a trichoderma harzianum strain and genome wide search for the genes. Genes 9(2): pii: E62.

28. Jo BS, Choi SS. 2015. Introns: the functional benefits of introns in genomes. Genomics Inform. 13: 112-118.
29. Kurachi S, Hitomi Y, Furukawa M, Kurachi K. 1995. Role of intron I in expression of the human factor IX gene. J. Biol. Chem. 270: 5276-5281.

30. Gniadkowski M, Hemmings-Mieszczak M, Klahre U, Liu HX, Filipowicz W. 1996. Characterization of intronic uridine-rich sequence elements acting as possible targets for nuclear proteins during pre-mRNA splicing in Nicotiana plumbaginifolia. Nucleic Acids Res. 24: 619-627.

31. Jun X, Zhen GZ. 2003. Intron requirement for AFP gene expression in Trichoderma viride. Microbiology 149: 3093-3097.

32. Gonzalez-Hilarion S, Paulet D, Lee KT, Hon CC, Lechat P, Mogensen $\mathrm{E}$, et al. 2016. Intron retention-dependent gene regulation in Cryptococcus neoformans. Sci. Rep. 6: 32252.

33. Kozak M. 2005. Regulation of translation via mRNA structure in prokaryotes and eukaryotes. Gene 361: 13-37.

34. Du M, Ye L, Liu J, Liu J, Yang L. 2008. Enhancement of GFP expression by Kozak sequence $+4 \mathrm{G}$ in HEK293 cells. Sheng Wu Gong Cheng Xue Bao 24: 491-494.

35. Olafsdóttir G, Svansson V, Ingvarsson S, Marti E, Torsteinsdóttir S. 2008. In vitro analysis of expression vectors for DNA vaccination of horses: the effect of a Kozak sequence. Acta Vet. Scand. 50: 44.

36. Li J, Liang Q, Song WJ, Marchisio MA. 2017. Nucleotides upstream of the Kozak sequence strongly influence gene expression in the yeast S. cerevisiae. J. Biol. Eng. 11: 25.

37. Mahadik ND, Puntambekar US, Bastawde KB, Khire JM, Gokhale DV. 2002. Production of acidic lipase by Aspergillus niger in solid state fermentation. Process Biochem. 38: 715-721.

38. Guang L. 2015. Purification and characterization of a lipase with high thermostability and polar organic solvent-tolerance from Aspergillus niger AN0512. Lipids 11: 1155-1163.

39. dos Santos EAL, Lima ÁS, Soares CMF, Santana L. 2017. Lipase from Aspergillus niger obtained from mangaba residue fermentation: biochemical characterization of free and immobilized enzymes on a sol-gel matrix. Acta Sci.Technol. 39: $1-8$. 